\title{
Struggling Teachers and the Recognition of Effective Practice
}

\section{Accepted Manuscript}

Brady, A. M. (2019) Struggling teachers and the recognition of effective practice. Journal of Philosophy of Education. https://doi.org/10.1111/1467-9752.12371 (In press).

\section{ALISON M. BRADY}

This paper discusses the ways in which the teacher is recognised through the formulation of evaluation frameworks which encompass criteria for so-called effective teaching and, by extension, effective learning. It argues that the emphasis on that which is 'effective', and therefore measurable, is symptomatic of an overly technicist understanding of teaching and learning, and the rapport between both. However, the recognition of the teacher as (in)effective in this way eclipses some of the other, more fundamental components of the act of teaching. Most importantly, the recognition that is conferred on teachers through effectiveness discourses serves to devalue the important 'struggle for recognition' that is inherent in such situations, and thus, fails to capture the lived, and often messy, experiences of being a teacher. Using the idea of the 'look' as explored by the philosopher Jean-Paul Sartre, as well as an example from the BBC TV programme 'Tough Young Teachers', this paper attempts to demonstrate what this 'struggle for recognition' looks like in classroom practice, why it is insufficiently accounted for in evaluation frameworks, and why it is important to consider when thinking about the work that teachers do.

\section{INTRODUCTION: CLAUDENIA'S LESSON}

It is not a rare incidence that a battle of wills is extant in the classroom, whether overtly or otherwise. For those in any doubt, the BBC TV programme 'Tough Young Teachers' offers some key insights into times when one can clearly see such battles ensue.

'Tough Young Teachers' (BBC Three, 2014) follows the lives of teachers undergoing their teaching placements as part of the 'Teach First' trainee programme in the UK. The programme portrays the trials and tribulations of being a teacher, highlighting some of the common issues that teachers often face, and is often 
punctuated with particularly poignant moments of vulnerability, especially for those teachers with little practical experience. Indeed, it is quite successful in demonstrating the often profound ways in which teachers stand exposed, unmasked and unguarded in front of a class, specifically in moments of apparent classroom upheaval.

In one such scene, we see Claudenia, a trainee science teacher, trying to enact what she imagined would be an effective strategy to demonstrate the phenomenon of sound. Claudenia is attempting something quite creative or 'whacky' (according to the programme's narrator), involving a select number of students standing in front of their peers and re-enacting how it is that sound vibrates and travels from its point of origin to its receiver. The students, now displaced from their usual spot behind their desks, start to act up, clearly frustrated with Claudenia's (lack of) directions and with what they have been tasked with (as indicated by one student who comments that the task 'didn't make no sense'). They seem to be ashamed in front of their peers, with another student commenting that Claudenia had 'made [them] look like idiots'. Claudenia, in turn, becomes visibly frustrated herself. She tries to power through, but ultimately caves into her perceived failure of the situation, and the awkwardness becomes all the more palpable when the students start to mockingly applaud her and their peers for their effort. But, of course, the lesson must go on.

Most of the students appear to completely lose interest in what she is explaining, and begin misbehaving, chatting loudly, and ignoring her. Upon hearing the 'racket' in the hallway, another seemingly more experienced teacher, Mr. McDonald, enters the classroom to check if Claudenia is having any problems. Through using his 'death stare', he manages to force the attention of some of the students. But this is only momentary victory, since as soon as he leaves, the chaos continues. The scene ends with Claudenia visibly upset, stumbling over her words as she asks the students to pack up, remarking later to a colleague that she doesn't know what she is doing, and that the students also do not know what she is doing. She then relegates the entire lesson as a waste of everyone's time.

This example serves as an interesting insight into concerns around how effective teaching is recognised, in public and in private, and in particular cases where established measures are in place in order to evaluate such practices. However, also of some concern might be how the teacher is recognised in such situations. The distinction between the two kinds of questions might not be immediately clear. However, upon reflection, this latter concern points to something altogether more shrouded and obscure, where the measure of the effectiveness of practice and behaviour becomes less important than the experiences and encounters teachers undergo when exposed to a classroom of students.

For example, when considering the first concern, how might an inspector evaluate this lesson, and what went wrong? He might say that Claudenia is certainly a knowledgeable teacher, with quite creative lesson ideas, but lacks the authority to conduct the class and direct the learning in an effective way. This lack of authority has made her less confident, and therefore, less able to get her message across. He may then offer feedback via a list of 'techniques' for evading or 'neutralising' this conflict in the future. Claudenia may be advised on certain 'behaviour management' techniques, or voice projection or even confidence training.

Much of what the inspector relies on, as we will see, are frameworks for effective practice against which the teacher's behaviour is measured. Whilst the above techniques for increasing the effectiveness of the lesson may work, albeit momentarily, they do not give due credence to the struggle that is always, inescapably taking place - the constant, deep-seated, visceral tensions that exist between students 
and teachers, or the sometimes explosive contestation that both teachers and students face in their interactions with one another. It is not merely a struggle to 'win' over one another, although that may also be an important part of it. It also constitutes the struggle to be recognised as a person.

What this paper tries to untangle, therefore, are the ways in which effective teaching is recognised through the formulation of frameworks which encompass criteria for so-called effective teaching and, by extension, effective learning. It argues that the emphasis on that which is 'effective', and therefore measurable, is symptomatic of an overly technicist understanding of teaching and learning, and the rapport between both. Much of this has come about due to the influence of school effectiveness research. The focus of this paper, however, is on the way in which the recognition of teaching as (in)effective in this way eclipses some of the other, more fundamental components of the act of teaching. Most importantly, the recognition that is conferred on teachers through effectiveness discourses serves to devalue the important 'struggle for recognition' that is inherent in such situations, and thus, fails to capture the lived, and often messy, experiences of being a teacher.

In order to understand such lived experiences more fully, I will begin by carefully considering what this term 'recognition' actually entails, and why it is significant for our lives in a myriad of ways. Following this, I will consider some of the ways in which effective teaching is recognised, as exemplified through the selfevaluation frameworks in the Republic of Ireland, arguing that such frameworks offer an impoverished understanding of recognition. I will then turn to the famous idea of 'the look' as explored in the work of the French existentialist, Jean-Paul Sartre, in order to expound upon what this 'struggle for recognition' consists in, and how this demonstrates certain aspects of teaching that are beyond the system of measurement that evaluation frameworks are premised upon. Since recognition is integral to the act of teaching, a richer understanding of this might also allow for a richer conception of teaching, one that goes beyond the technicist understanding of teaching and learning made manifest in the way that teachers are often evaluated.

It is important to note that, rather than using Sartre to offer a normative framework by which we can firmly establish what authentic teacher--student relationships consist in, this paper instead attempts to grasp some aspect of the implicit ontological conditions of what it means to be 'existentially exposed' in the classroom, and how this is experienced through evaluation. In other words, whilst the approach of recognition through effective evaluation frameworks is problematised, this alternative notion of recognition should not be directly conceived of as a substitute approach but rather, it serves as a description of teaching itself, in line with Sartre's phenomenological approach. ${ }^{1}$

Having said that, in coming to terms with this, the questions one asks during inspections or evaluations may shift from being concerned with 'what works' or 'what is effective' to being more focused on these lived experiences of being a teacher. Thus, the very nature of teacher appraisals may need to be rethought in light of this richer sense of recognition, which the paper will briefly allude to towards the end.

First, let us consider what it is that is meant by the term 'recognition', and why it is significant for our discussion here.

\section{UNDERSTANDING RECOGNITION}

The notion of recognition is multifarious and can encompass both everyday as well as more 'abstract' usages. When we think of recognition, for example, we may imagine 
unremarkable instances which we automatically associate with the term. Such instances include, perhaps, being recognised on the street by a friend. Our hard work and effort may be recognised and lauded through praise and applause. A medical doctor in uniform will be immediately recognised as such (mistakenly or otherwise) because of this visible manifestation of his job, and this recognition can come about despite not knowing who this doctor is in any personal sense.

Outside of this, however, the term becomes altogether more complex. It may be used in the form of legal jargon, exemplified when, for example, the Irish Republic voted in favour of giving equal legal recognition to same-sex marriages as to heterosexual ones (The Irish Times, 2016). Recognition through a form of profiling is often used in law enforcement, where one's particular social status, traits or appearance are seen to be inevitably tied to particular expectations or predictions of behaviour, however erroneous these predictions might be. A commonly cited example of this occurs when people of particular demographics are disproportionately stopped by police since they are recognised as fitting a specific 'profile' of a suspect more broadly (Kocsis and Palermo, 2007, 2015).

What philosophers of recognition, ${ }^{2}$ such as Charles Taylor, argue is that the recognition conferred on us by others is often constitutive of how we understand ourselves and our identity. Of course, there are certain conditions which make or exclude such acts of recognition from impacting on the ways in which they may be said to influence, or indeed constitute, our identity. Those recognising us must be individuals we consider as 'significant others', to use Taylor's (1991, 1994) terminology. They must be viewed as persons with the capability and authority to confer (or withhold) recognition on us. Recognition which is coerced is inauthentic and ultimately fails, as explored by Hegel in his master-slave dialectic (Hegel, 1807).

Furthermore, to consider recognition as an important facet of our identity, one needs to accept that identity is inter-subjectively formed. Identity here is understood as that which is dialogical-it is not forged in isolation, but through our interaction or encounter with others, as well as the wider communities to which we belong. According to Taylor $(1989,1991,1994)$, it is in such communities that we develop our 'horizons of significance', wherein which we work out and assume our identity. This identity is never entirely fixed. Rather, it is perpetually (re)formed in light of the various circumstances or situations we find ourselves in, those environments against which we struggle or to which we submit, or by virtue of different individuals we may encounter or interact with, who inevitably recognise us in a particular way (Brady, 2016).

Thus, recognition occurs in particular frameworks, according to Taylor. But these 'frameworks' are not the technicist kind that are often established as a way to profile and measure effective practice, as we will see below. Rather, Taylor's understanding of frameworks are those that allow us to apprehend the world in a particular way - they are the wider horizons in which we are situated, and in which we make sense of the world and our place within it.

Thus, identity is partly forged through frameworks in which recognition is conferred on us by others. However, this act of recognition does not occur in any inert sense. Often it may seem as though we are 'fixed' in our identity through impoverished forms of recognition. Indeed, we may become entombed by the recognition that others confer on us, convincing ourselves that the qualities others see in us are accurate descriptions of who we are. And yet, as we will see below, identities are something we struggle with, and often against, and this is made manifest in such instances where the struggle for recognition is palpable, such as in the classroom. 
Indeed, classrooms might be understood as a site where 'fusions of horizons' (Gadamer, 2004) occur and where, as we will see below, the acts of recognition thus become all the more profound. These 'horizons', and the acts of recognition that come about by virtue of them, are often inarticulable, or are at least, difficult to explicate in any clear sense. This is because they often encompass implicit ideas we hold about the world, garnered from our years of being in the world, and therefore, differ to a great extent from the kinds of normative, externally established 'frameworks' made explicit in inspection policies.

The example of 'profiling' suspects serves well to identify some impoverished forms of recognition. If we are to encounter others purely by virtue of certain 'profiles' we have of them, where certain expectations for their behaviour thenceforth come into play, then one could argue that we are limiting the extent to which those individuals could become something other than what their profiles suggest. Furthermore, such forms of recognition conferred from the outside often come to be how one views oneself, as demonstrated by Fanon (2001) among others. In other words, the ways in which others recognise us, impoverished or otherwise, come to be how we identify ourselves. This identity, in turn, becomes difficult to discard.

In terms of the acts of teaching, the mechanisms behind such impoverished forms of recognition are clear. In order to demonstrate this further, let us consider some examples from the context of the Republic of Ireland, where 'profiles' of effective practice are used to gauge the quality of teachers and, by extension, learners.

\section{RECOGNITION OF EFFECTIVE TEACHING THROUGH SELF- EVALUATION 'PROFILES'}

When it comes to teaching and learning, one of the primary aims of inspection policy is to measure effectiveness. It is often argued that effective teaching has the greatest impact on the attainment levels of pupils (DES (Ireland), 2016a, 2016b; Hattie, 2008). The general sentiment seems to align with the idea that effective teaching, more often than not, generates an effective lesson, which in turn produces effective learners. In a similar vein, ineffective teachers are often thought to lead to ineffective learners.

But what exactly do we mean by 'effective'? In recent years, the term 'good' has been used interchangeably with the term 'effective' in the policy of teacher inspection or, in the case of Ireland (DES (Ireland), 2016a, 2016b), has been almost entirely replaced by the latter. Prominent inspection educationalists, such as John MacBeath (1999), suggest that the hunt for the 'good school' is akin to hunting a unicorn-some mythical endeavour which is seemingly never obtained. Whereas the 'good' in education might be considered to be a kind of teleological ideal towards which we move but never fully attain, 'effective' takes a much more hard-line stance. One of the primary differences between positing a 'good' teacher and an 'effective' one, for example, may be to do with the level of accuracy in how one can measure such qualities. A 'good' teacher appears to be somewhat relativistic or subjective, in the debased sense of the term. On the other hand, an 'effective' teacher is seen to be more easily identified using objective, verifiable 'evidence' of some kind, on the basis of certain performance indicators the inspectorate might establish against which this effectiveness can be gauged.

Arguably, such ideas have been influenced by the prevalence of school effectiveness research, which, understood simplistically, seeks to equate effective teaching with desired learning outcomes (Goldstein, 1997). The kinds of factors which impinge on the level of effectiveness of schools, according to this body of 
research, are often uncontroversial or 'common sense' (see, for example, Killen, 2006). Whilst effectiveness researchers often add the disclaimer that what their research shows us are correlations, and not explanations, such findings are often conceived of in policy literature as recipes or clear demarcations of what 'effective' practice should look like. Indeed, this certainly seems to be the case when considering the ways in which teachers, and by extension learners, are evaluated in the Republic of Ireland.

In relation to inspection, this often involves taking due consideration of a particular 'profile' of effectiveness which is usually externally generated via a clearly formulated 'framework', even, as we will see below, in inspection policies which focus on internal rather than external review systems. Although this term 'profile' is not used explicitly, the idea is that, in correspondence with the criteria set forth in inspection handbooks (DES (Ireland), 2016a, 2016b), an ideal description of the teacher is posited, and the exercise of recognising effective teachers becomes much simpler, more standardised and more efficient as a result. ${ }^{3}$

Indeed, this description serving as a 'profile' falls broadly in line with the criminological usage of the term. 'Profiling', according to Kocsis and Palermo (2007, 2015), is a forensic technique commonly used in law enforcement, wherein which a homology of a criminal offender is posited in order to aid the analytic process behind determining and predicting criminal behaviour. Indeed, profiling is not simply used to identify and interpret criminal behaviour, but it is also used predict the personality of offenders, their modus operandi, and their possible motivations for the crime. In teaching, certain profiles for effectiveness might be established not only as a way in which to interpret behaviour, but also as a way to guide future practice.

Rigorous teacher inspection systems which rely on such profiles can arguably be seen in the likes of Ofsted in England, a body which has often been criticised for its overly intrusive and invasive procedures for appraising the practice of teachers (Richards, 2015). However, it is worth noting that there are also more seemingly innocuous or 'cautious' (NcNamara and O'Hara, 2008) forms of teacher evaluation that do not seem to take this hard-line, punitive stance, such as 'self-evaluation' in the Republic of Ireland. ${ }^{4}$

The Republic of Ireland, instead, has adopted a combination approach to inspection often referred to as 'smart regulation'. Such regulation comes in the form of school self-evaluation, a method of internal review, which is then complemented by external inspections whose primary function is to motivate and support this process. This dual form of regulation is 'smart', not only because it is cost-effective, but also because it seemingly offers greater ownership over the ways in which schools and their teachers self-evaluate their practices, whilst also upholding the principle of school accountability through greater responsibilisation of schools (Simons, 2015). ${ }^{5}$

Using a diagram (See Figure 1) designed by Schratz et al. (1998), the prominent self-evaluation researcher, John MacBeath $(1999$, p. 3) emphasises the need for a balance between external and internal evaluation, since when that 'point of balance is achieved, people are enabled to do their job most effectively because they experience intrinsic satisfaction as well as extrinsic recognition and reward' (MacBeath 1999, p. 2). 
Figure 1. Why schools must speak for themselves: Three dimensions of school evalaution and development (MacBeath, 1999, p. 2).

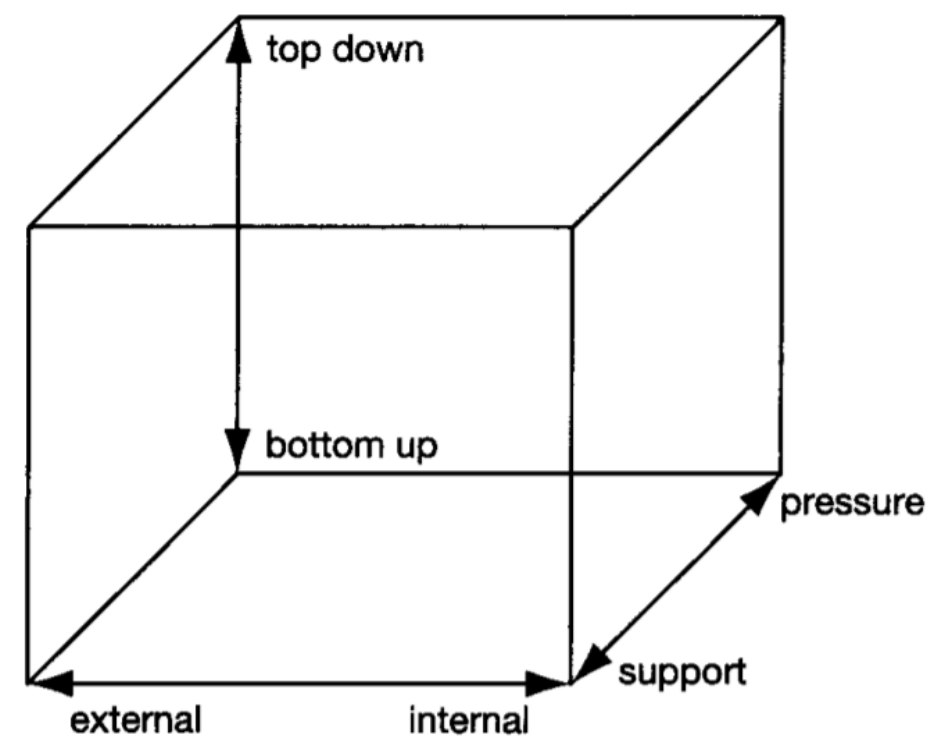

In order to achieve this balance, it was considered that both internal and external evaluation should adopt the same profiles of effective teaching. Alluding to this idea, the Chief Inspectorate of Ireland, Harold Hislop (2012) remarked that:

A responsive regulatory system cannot operate effectively unless everyone involved is clear about the standards against which the service is to be judged. This means that if we are to use a combination of external inspection and school self-evaluation, we must articulate a clear set of standards against which the work and outputs of schools can be judged.

In 2016, this was achieved with the establishment of a common inspection framework for both internal and external evaluations of schools, with a specific emphasis on teaching and learning, entitled Looking at Our Schools: A Quality Framework for (Post-)Primary Schools (DES (Ireland), 2016b). In it, we see various criteria of what 'effective' and 'highly effective' teaching looks like (See Figures 2 and 3). The quality framework is quite complicated and extensive, to say the least. For the purposes of this paper, I will focus exclusively on the kinds of profiles of effectiveness that are offered throughout, rather than the systematised process by which self-evaluation is undertaken. ${ }^{6}$

Consider this example of the difference between effective and highly effective teaching (See Figures 2 and 3): 
Figure 2. Example of teachers' standards, statements of effective practice and statements of highly effective practice from 'Looking at Our Schools' (DES (Ireland), 2016b, 17).

\section{DOMAIN 3: TEACHERS' INDIVIDUAL PRACTICE}

\begin{tabular}{|l|l|l|}
\hline \multicolumn{1}{|c|}{ STANDARDS } & \multicolumn{1}{c|}{ STATEMENTS OF EFFECTIVE PRACTICE } & \multicolumn{1}{c|}{$\begin{array}{c}\text { STATEMENTS OF HIGHLY EFFECTIVE } \\
\text { PRACTICE }\end{array}$} \\
\hline $\begin{array}{l}\text { The teacher has } \\
\text { the requisite } \\
\text { subject } \\
\text { knowledge, } \\
\text { pedagogical } \\
\text { knowledge } \\
\text { and classroom } \\
\text { management } \\
\text { skills }\end{array}$ & $\begin{array}{l}\text { Teachers have the required professional } \\
\text { qualifications and have engaged in a range of } \\
\text { continuing professional development (CPD). }\end{array}$ & $\begin{array}{l}\text { Teachers have the required professional } \\
\text { qualifications and have engaged in a range of } \\
\text { continuing professional development (CPD) } \\
\text { relevant to students' learning. }\end{array}$ \\
$\begin{array}{l}\text { centred learning environment based on } \\
\text { mutual respect, affirmation and trust. }\end{array}$ & $\begin{array}{l}\text { Teachers create an inclusive, orderly, student- } \\
\text { centred learning environment based on } \\
\text { mutual respect, affirmation and trust, in } \\
\text { which students regulate and monitor their } \\
\text { own behaviour. }\end{array}$ \\
\hline $\begin{array}{l}\text { Teachers have high expectations of students' } \\
\text { work and behaviour, and communicate these } \\
\text { expectations effectively to students. }\end{array}$ & $\begin{array}{l}\text { Teachers have high expectations of students' } \\
\text { work and behaviour, communicate these } \\
\text { expectations effectively to students, and } \\
\text { facilitate students in internalising them. }\end{array}$ \\
\hline
\end{tabular}

A similar lay-out is designed in the framework for effective and highly effective learning (DES (Ireland) 2016b, p. 15):

Figure 3. Examples of students' standards, statements of effective practice and statements of highly effective practice from 'Looking at Our Schools' (DES (Ireland), 2016b, p. 15).

\begin{tabular}{|l|l|l|}
\hline $\begin{array}{l}\text { Students grow } \\
\text { as learners } \\
\text { through respectful } \\
\text { interactions and } \\
\text { experiences that } \\
\text { are challenging and } \\
\text { supportive }\end{array}$ & $\begin{array}{l}\text { Interactions among students and between } \\
\text { students and teachers are respectful and } \\
\text { positive, and conducive to well-being. }\end{array}$ & $\begin{array}{l}\text { Interactions among students and between } \\
\text { students and teachers are very respectful } \\
\text { and positive, and conducive to well-being. }\end{array}$ \\
$\begin{array}{l}\text { Relationships and interactions in classrooms } \\
\text { and learning areas support a co-operative } \\
\text { and productive learning environment. }\end{array}$ & $\begin{array}{l}\text { Relationships and interactions in classrooms } \\
\text { and learning areas create and sustain a } \\
\text { co-operative, affirming and productive } \\
\text { learning environment. }\end{array}$ \\
& $\begin{array}{l}\text { Students' experiences as learners generally } \\
\text { reflect well on how the code of behaviour } \\
\text { is understood and implemented. }\end{array}$ & $\begin{array}{l}\text { Students' experiences as learners reflect } \\
\text { consistently well on how the code of } \\
\text { behaviour is understood and implemented. }\end{array}$ \\
$\begin{array}{l}\text { Students feel able to contribute their } \\
\text { opinions and experiences to class } \\
\text { discussion. They listen respectfully to } \\
\text { the opinions and experiences of their } \\
\text { classmates. }\end{array}$ & $\begin{array}{l}\text { Students contribute their opinions and } \\
\text { experiences to class discussion with } \\
\text { confidence. They are respectful of and } \\
\text { interested in the opinions and experiences } \\
\text { of their classmates. }\end{array}$ \\
\hline
\end{tabular}

All of this seems quite reasonable. It seems almost obvious that a student is most likely happier in a classroom which is orderly and respectful, where there exists a safe space in the classroom to air opinions and where both students and teachers abide by 
the same rules for conduct. In the case of Claudenia's classroom, for example, her situation and her perception of the lesson would have been most likely enhanced had the students behaved in this way.

And yet, are such descriptions of effective practice always conducive to 'effective' learning? How do we know? Can teaching and learning be measured in accordance with these standards of effective and highly effective practice? The inspectorate certainly seems to think so, and this is made evident by the tools that are suggested for teachers to gain reliable evidence which supports their findings. These include student or parental questionnaires on how much they enjoy school, observations on how students behave outside and inside the classroom (an example MacBeath offers is to calculate how often in the day an older student is seen helping or speaking to younger ones), a time log which calculates the amount of time a teacher raises her voice in the classroom.

What is being pushed here, then, is that recognising an effective teacher means using the tools at one's disposal to measure the extent to which the profiles above are obtained. A teacher may fall on the 'effective' continuum, and thus must continue to work towards becoming 'highly effective'. Had Claudenia managed to control her classroom in this way, she may have been considered as highly effective. But the question remains - in what way is she effective (or not), for what reason, and for whom? What does it mean to say that Claudenia is an (in)effective teacher? Is that all that she is in these circumstances? And if not, then how are we to go about measuring her effectiveness in those terms?

Effectiveness profiles as exemplified above seem to understand teaching as a technical endeavour, and arguably, the profiles put forth for measuring effectiveness represent a clinical and overly reductive understanding of what being a teacher often constitutes, how teaching and teachers are recognised, and how it might relate to learning. Rather, the practice of teaching and its relationship to learning, I argue, is more accurately portrayed with a deeper understanding of the struggle for recognition that is often palpable in classroom practice, a struggle made visible in such classroom situations as Claudenia's science lesson. But in order to articulate this 'struggle' further, and to show how it is pervasive in the acts of teaching and learning, let's turn now to Sartre's idea of 'the look'.

\section{SARTRE AND THE STRUGGLE FOR RECOGNITION}

Sartre's post-war literature certainly paves the way for a succinct understanding of a theory of recognition (see, e.g. Sartre, 1946), but for the purposes of this paper, I would like to explore this idea on a more ontological level, where it appears most explicitly in his thought, and wherein which the emphasis on the lived experiences of recognition comes to the fore. This is most overt in the chapter on 'Being-For-Others' as discussed in his seminal work, Being and Nothingness (Sartre, 1943), which contains one of his most steadfast ideas - that of the look of the Other.

Sartre's philosophical work on the whole is strewn with familiar examples where the pervasiveness of such experiences as recognition is demonstrated. Through the use of the concept of 'shame', for example, Sartre is able to make us acutely aware of the fact that we always exist before others. When I am performing some kind of vulgar act, I can continue to do so unhampered until I realise, or suspect, that another is watching me, after which I feel I have been exposed. This feeling of vulnerability, and the shame that accompanies it, is immediate. It does not come about through reflection, through gauging or measuring the situation, through judging 
myself as 'one who should feel ashamed'. Rather, according to Sartre (1943, p. 221), 'I simply live it'. This sense of shame and exposure can only happen through our existence in relation to other people, and it comes about, for Sartre (1943, p. 261), through the 'recognition of the fact that I am indeed that object which the Other is looking at and judging'.

This is explored further in one scene in 'Being-For-Others', where Sartre examines the feeling of being alone in a park, surrounded by things which seem to be specifically organised in a way which serves the notion of me, as a subject, being the focal point of the scene. These things are imbued with specific qualities which I consider exterior from me, things which I assign meaning to, and which I, as a selfconscious being, negate as 'not being me'. Ultimately, therefore, I am the central point of reference in the scene. I am a pure subjectivity-isolated, radically free and without tension.

However, as the narrative progresses, other people begin to appear, first assuming the identity of mere objects or accessories amidst the landscape, like trees or benches. One person, now aware of my presence, looks directly at me and suddenly, my situation is severely altered. I become aware of the existence of another frame of reference who has invaded my world, their world becoming superimposed on mine, wherein I, consequently, then figure as a mere accessory or object. My own world begins to disintegrate entirely. Parts of my world, the world of accessories, has now drained and have become part of the Other's, and I become that which is placed at a distance from that other self-consciousness who now becomes the focal point of the scene.

This, according to Sartre (1943), is what is more commonly known as the look of the Other. There is a movement from being the observer to being the observed, from being the subject in the scene to being the object for another. I begin to feel vulnerable and embarrassed. This vulnerability acts as a limitation on my subjectivity, and I am no longer radically free as before. To counteract this, I attempt to negate the other as I negate other objects in the world, by saying that this other is not me, and therefore, I come to define myself as that which is other than this Other. I do so in order to reassert my freedom as an independent subjectivity. Yet their gaze makes me aware of the Other as also negating my subjectivity, and this act of reciprocal negation remains entwined within a state of struggle. I do not exist without the Other, and yet, their existence acts as a limitation on what I am, or how I see myself. This struggle is perpetual, and the vacillation between being-as-object and being-as-subject seems to be inescapable.

What Sartre is expounding here is akin to the struggle for recognition, conceived of as an ongoing tension between one's attempts to avoid being objectified and, in doing so, affirming one's own subjectivity. Yet with the presence of the Other, the former is impossible to evade. It is for this reason that Sartre (1944) would later say, 'Hell is other people'. Indeed, since we will always exist in the world with others, this struggle is impossible to overcome (Heter, 2006), except through 'bad faith" ${ }^{7}$ where the anguish of such limits to our freedom can be circumvented somewhat. However, this, for Sartre (1943), is the defining feature of inauthenticity. ${ }^{8}$

Furthermore, as Sartre (1943) rightly identifies, the Other need not be physically present for this feeling of objectification to arise. Merely being in a world where others exist can evoke this experience nonetheless. As we have seen above, if one is acting shamefully, then one feels ashamed, regardless of whether or not one is being watched at that moment. Indeed, one is always 'existentially exposed' to the Other (Sartre, 1943), and this exposure is part of what defines us as human beings conscious 
of such facts of existence, which in turn impacts our own self-understanding, or selfrecognition.

Sartre's 'look' is certainly reminiscent of what a teacher often feels like amid an inspection, where they experience a heightened sense of awareness in terms of how they are performing. What inspections tend to do, or are in danger of doing, is to consider the practice of a teacher as somewhat distinct from their identity as teachers, as something which can therefore be measured, benchmarked and compared with what is laid out in the profiles of effectiveness. This is not to deny that, of course, there are some things in education and in the practice of teachers that can be measured in accordance with these profiles. But to focus solely on this more technical understanding of teachers, learners, the lesson, and indeed the relationship between all of these, is to deny the struggle for recognition that is inescapably taking place, whether obvious or otherwise.

Furthermore, this impoverished or 'technical' form of recognition is significant in that it might result in being seen as having a fixed sense of identity. If we are to consider more technical professions, where the goals and purposes of one's job is quite clear and distinct, then the idea of fixing identity through recognition does not seem all that problematic, perhaps. If I look at a ticket inspector, in uniform, on the train, then I can trust almost immediately that that person is there to do a specific task. I can even measure the extent to which he has performed that task correctly. Has he checked all of the tickets? If he hasn't, it may be easier to judge the extent to which he is performing his duties effectively. And whilst the ticket inspector has an identity which is also subject to the struggle for recognition I have outlined above, I am less concerned about this at that moment. It doesn't seem central to the task he is set to perform, or to the ways in which one can measure how well he has done so.

What makes this so much more difficult to liken with the act of teaching? Unlike the train conductor, one could argue that the teacher is 'existentially exposed' in an even more acute and pertinent way, since part of their work necessarily involves standing in front of a group of 'others' (i.e. students) in a visible and often performative sense. As Standish (2014) points out, it is often through teaching that we become aware of our individual attributes or dispositions that we had not realised before-certain mannerisms we demonstrate or perhaps particular ways of speaking we had not realised. This is due to the teacher being exposed in the classroom, and it is through this exposure that the struggle of recognition is so palpable. Unlike the train conductor, the very identity and personhood of the teacher is on display, making it more open to the forces of recognition.

This is made more salient in the process of inspection, but it is also indicative in the very act of teaching itself. Claudenia may be offered advice on how to improve her level of effectiveness, but should the focus remain solely on this, then we are failing to see that she is not just a teacher, or at least a teacher in the technical sense. What happens in the classroom directly affects her because it is not just her 'function' that is on display. It is also her very personhood that is exposed. ${ }^{9}$

And yet, a teacher is often recognised as 'effective' in a similar way to the train conductor, i.e. as meeting the conditions of a particular profile. But teachers often do not adorn themselves with uniforms and wield their badge of identity in such a visible way. Sometimes they perform so as to keep this identity hidden from their pupils. Sometimes events happen unexpectedly in a classroom that puts this identity in question. Sometimes pupils misrecognise the intentions and capabilities of the teacher, as we have seen in the case of Claudenia. Sometimes this misrecognition comes to be how the teacher understands her own practice, regardless of how 
'accurate' it might be. Sometimes pupils purposefully withhold recognition from a teacher, in some kind of act of defiance. This recognitive relationship often wavers and fluctuates, in accordance with particular situations in the classroom, and also with the specific content of the lesson that is being dealt with. The oscillating melee between being objectified, on the one hand, and asserting one's authority as a subject, as demonstrated in Sartre's park scene, is not simply settled by employing mechanised tactics or universal methods founded upon principles such as the transference of good practice. Rather, it is part and parcel of the very nature of teaching itself.

\section{STRUGGLING TEACHERS}

So what does all of this tell us about Claudenia's lesson, and how we can capture what it is that is going on? Let us think about the two ways in which we can approach this in terms of recognition.

In inspection policies, we have a neater understanding of what constitutes effective teaching, coupled with particular techniques to overcome ineffectiveness. These neater understandings allow us to more clearly recognise what it is that is going on, and how we can go about addressing it. Of course, such forms of recognition are important, as are the techniques that we may introduce to alleviate certain difficulties that Claudenia is facing. Perhaps she could learn to be more confident, more authoritative, surer of how the lesson will pan out, and whether or not her pedagogical ideas would work. What the framework for self-evaluation requires in addition to these is that any judgements made on the quality of our practice need to be measured. But what would such measurement look like? And is there something that such measurements are missing out on?

Indeed, there are also arguably more fundamental aspects of the situation that also cannot be ignored. Without wishing to psychologise this event and what went wrong, there are certain questions one could ask that would offer very different answers, answers that are not immediately conducive to measurement in terms of levels of effectiveness. Why is it that Claudenia is experiencing what seems to be a withholding of recognition from her students? Why is it that, when Mr McDonald enters the room, he manages to be immediately recognised as someone with authority, worthy of respect and attention? Does he undermine Claudenia further, through using his 'death stare' in trying to force recognition from the students? Why does Lucas, one of the students, feel ashamed when exposed in front of his classmates? Why isn't he more polite to Claudenia when she asks him to be? What is it that makes Claudenia so upset when the lesson ends? ${ }^{10}$

These questions are not so concerned with 'what works' or 'what was effective' in the lesson. They are not questions that fit into the technical framework of effective teaching, as outlined in inspection policy. They are not questions that can be 'measured' in any accurate way, through the collection of data or through the process of benchmarking and comparison. Rather, they are more existential questions that attempt to articulate this struggle for recognition, and are ultimately confronted with the indication that doing so is very demanding, if not impossible.

Partly, this has to do with the understanding that, as mentioned, teaching affects one's entire personhood in a way that if it were to be understood in a purely technical sense, would make little sense, since the act of teaching is very much embedded in the struggle for recognition through the look of the Other. Indeed, it is not simply that Claudenia wants to be recognised by her students, by Mr McDonald, or by us as 
viewers, as a good teacher, with the ability to do her job effectively. Rather, it seems as though Claudenia wants to be recognised as a person.

\section{CONCLUSION}

Thus, we seemingly have posited two very different kinds of recognition. One may be described as a 'fixed' or 'fixable' form of recognition, and relates to the kinds of profiles we often establish in order to understand the other. This form of recognition is reductive, and ultimately leads to an impoverished understanding of what teaching actually entails, which, as I have argued, cannot be understood in a purely technicist or measurable way. Furthermore, this kind of recognition can be grievous, since it often bars a more authentic encounter with the Other in the sense that our predetermined ideas of what their identity constitutes not only fails to do justice to the intricacies of such identity, but can also harm the other themselves when such identities become adopted as their own. It is also dangerous in the sense that it may entomb our understanding of the role of a teacher as a technical deliverer of curricula knowledge, a cog in the grand scheme of ensuring viable knowledge-based economies.

On the other hand, the more ontological or 'existential' idea of recognition suggests a struggle, where the 'fixing' of identity becomes a twofold process, an endless, often inarticulable, fluctuation between the objectification and subjectification of oneself and the Other. This, according to Sartre at least, is not something we should 'aim' for as such-it is simply how we are in relation to others.

Indeed, I do not wish to argue that recognition need be avoided. In fact, the acts of recognition as illuminated through the philosophy of Sartre are inescapable. Rather, they are part of the very substance of our being. One simply cannot teach without being exposed in some way, and this exposure necessarily involves sometimes subtle, sometimes more obvious, struggles for recognition that are inexorable and, often, inexplicable. What Sartre describes are facets of our everyday life, in that they examine the deep and important ways that the presence of the Other continually (re)configures how we understand ourselves and who we are.

Perhaps it is not just the inspection systems that need to change, per se, but also the way in which they impose a particular image of teaching on teachers (and, by extension, students), one based on a reductive model of effectiveness, coupled with an assumption that everything that teachers do needs to be measured by virtue of these models. Instead of offering techniques or tips for conflict resolution in classrooms, we must allow the participants to live with such tensions, since the tensions embodied in the struggle for recognition are part of what it means to be a teacher, and not just in terms of having particular 'functions'.

Or it might be that such techniques need to be 'updated' or 'experimented with'. But even 'tried and tested' techniques do not always work in every situation. As Taylor (1989, 1991) would say, 'la lotta continua'"1 regardless of what new techniques, policies or profiles we introduce. And part of this has to do with the minutiae of the relationship between teachers and learners, a relationship that very much encapsulates a struggle for recognition as I have indicated above. How can such a struggle be measured? And, if it cannot be measured, how can we evaluate its effectiveness? More importantly, why should we?

These are all pertinent questions that in the seeming urgency of inspection policy often become lost. And yet, they are invaluable questions that need asking, since in some respects, they get to the core of what being a teacher is all about. 
Correspondence: Alison M. Brady - UCL Institute of Education, 20 Bedford Way, WC1H 0AL, London, United Kingdom

Email: alison.brady.14@ucl.ac.uk

\section{NOTES}

1. In numerous texts, Sartre refers to the phenomenology of Husserl as a descriptive science, and his brand of existentialism is centred on the same idea-i.e. not in providing an abstract philosophy retrospectively applied to human situations, but to get to the cusp of what it means to be a human in the descriptive sense, starting from the (view)point of the human subject. See, for example, Sartre's discussion of phenomenology in his essay Transcendence of the Ego (1936).

2. There are a number of philosophers that may be termed in this way, since their work explicitly addresses questions of how and why we recognise and are recognised by others, each having different, albeit interrelated, foci and aims. Kant, for example, was concerned with how to ensure recognition in the form of mutual respect between autonomous persons. Taylor is primarily focused on how different social or cultural groups can receive some form of positive recognition from each other in order to flourish in a multicultural society, especially in cases where cultural values seem to clash (See, for example, his 1994 essay entitled Multiculturalism). More recently, philosophers such as Axel Honneth consider recognition in the context of social psychology-i.e. how recognition relates to identity formation and the question of authenticity where individuals find themselves in collective, intersubjective environments. All of these thinkers are in stark contrast with the approach that Sartre takes in his earlier works, however. Honneth, for example, follows the line of argumentation (inspired by Hegel) that considers how interpersonal relationships can and should lead to a form of self-realisation, where one ultimately becomes a unique, irreplaceable person. Recognition in light of this is a condition for the consciousness of individuality, thus leading to the development of a particular, authentic self. $\mathrm{He}$ explores this by delineating criteria in which a communal space allowing for this form of self-realisation is created and sustained. These involve what he calls three 'patterns' of intersubjective recognition. These are (1) love-in families or friendships where support is offered in the form of approval or encouragement, both of which are recognitive in nature; (2) law-in which there is public recognition of individual autonomy; and (3) solidarity - which concerns the recognitive forces involved in how we treat others, in how we recognise ourselves as (not) belonging to certain 'groups' 
etc. Sartre, however, seems to deny (or avoid) the question of the 'authentic self', particularly in his earlier works. Instead, he explores the ways in which we often act inauthentically, primarily through choices we make in bad faith. Rather than offering a normative account of what might allow for fair and equal recognition of individuals and groups, however (since he also strongly rejected forms of what he deemed 'abstract' or normative accounts for living), he attempts instead to describe what being in this recognitive relationship actually feels like, considering that his approach is phenomenological in nature. For more discussion on the former approach, see Honneth's (translated) work, The Struggle for Recognition: The Moral Grammar of Social Conflicts (1996).

3. This emphasis on effectiveness is also symptomatic of a wider audit culture which has become increasingly prevalent in recent years. In several different contexts, this is linked to the perceived importance of building a knowledge-based economy for the purposes of obtaining competitive advantages in the global market, wherein which education is considered key (see, e.g. Harris, 2007; Hislop, 2012; Richards, 2001; 2015; Simmie, 2012). Under the moniker of quality assurance, this process has resulted in increased levels of monitoring and evaluation of teaching on both external and internal planes. This further corresponds to a wider trend towards neo-liberal policymaking in education, which emphasises such mechanisms as transparency and accountability in the practice of classrooms, reinforced by the continued institutionalisation of rigorous inspection regimes in schools.

4. Indeed, inspections in Ireland are primarily based on internal review, a trend that has increased globally in the field of teacher evaluation (Grek and Lindgren, 2014). Indeed, internal review was even attempted in England (despite it often being criticised for having an overly 'top-down' approach) through the so-called 'new relationship with schools' established by the then-Education secretary, David Miliband in 2004. Whilst self-evaluation in Ireland claims to provide more scope for teachers and schools in formulating their own developmental plans, it also aims to inculcate teachers into a particular 'language of evaluation', and this often results in the profiles in the evaluation frameworks being adopted almost directly by teachers in their own evaluations. Thus, despite its apparent intentions, self-evaluation does not necessarily lead to the promise of 'greater ownership' over improvement, but rather universalises the ways in which effective practice in recognised at both the policy and the classroom level. This can be evidenced by a number of 'best practice' self-evaluation reports from 
schools available on the Irish inspectorate's website, schoolself-evaluation.ie. Furthermore, the use of self-evaluation as a way to promote greater autonomy for schools and teachers is met with greater levels of accountability. These more suspect motives are often hidden behind a rhetoric of greater ownership over developmental goals, and should thus be met with caution. (For a more sustained critique of these conflicting motivations, see Brady, 2019.)

5. This idea of smart regulation is summarised by MacBeath $(1999$, p. 1) who refers to 'educationally healthy' systems of self-evaluation as follows: 'It is an index of a nation's educational health when its school communities have a high level of intelligence and know how to use the tools of self-evaluation and self-improvement ... Its primary goal is to help schools to maintain and improve through critical selfreflection. It is concerned to equip teachers with the know-how to evaluate the quality of learning in their classrooms so that they do not have to rely on an external view, yet welcome such a perspective because it can enhance and strengthen good practice.'

6. It is worth briefly mentioning that schools are currently expected to focus solely on the practices of teaching and learning, since as mentioned previously, that is thought to have the greatest impact on the quality of schools. It is also important to note that the framework is emphatic about the use of evidence to back up any judgements made in relation to these criteria, and offers a number of tools available to schools for the purposes of qualitative and quantitative data collection. Arguably, this emphasis arose mainly in reaction to the idea of self-evaluation being considered as a 'soft option', one incapable of producing the rigorous, unbiased descriptions of the practice of teachers that external inspections could deliver (NcNamara and O'Hara, 2008).

7. Where, for example, I freely accept that I am an object, and treat myself or behave in this way. But this is inauthentic, for Sartre, since it denies the extent to which one is always free, even if that just means responding to situations in which we appear to be unfree. 'Bad Faith' is dealt with more succinctly in Part I Chapter 2 in Being and Nothingness.

8. The term 'authenticity' is implicit in much of Sartre's writings, but it is referred to only very minimally in Being and Nothingness. It is important to recognise that 'bad faith' is inherent (and, indeed, inescapable) in much of what we do, and on one level, Sartre is not discussing this idea in an accusatory sense, but rather, sees it as descriptive element of human experience that is central to the human condition. 
9. The often emotional aspects related to teaching, such as feelings of shame and vulnerability, are referred to in Britzman's (2010) text, The Very Thought of Education: Psychoanalysis and the Impossible Professions.

10. Not mentioned here is the fact that Claudenia is not just an inexperienced teacher, but she is also female and black, and such aspects of her identity may very well play a role in the struggle for recognition she encounters. Indeed, her authority is certainly lacking in comparison to the more experienced teacher, Mr. McDonald, who also happens to be male and white. Such questions, as posed here, are worth considering when inspecting the work that teachers do, and their capabilities in terms of effective practice may very well impinge upon such facets of their identity.

11. Translated as 'the continuous struggle' (Taylor, 1989).

\section{REFERENCES}

Brady, A. M. (2016) The Regime of Self-Evaluation: Self-Conception for Teachers and Schools. The British Journal of Educational Studies, 64.1, pp. 523-541.

Brady, A. M. (2019) Anxiety of Performativity and Anxiety of Performance: Self-Evaluation as Bad Faith, Oxford Review of Education [online] https://doi.org/10.1080/03054985.2018.1556626

BBC Three (2014) Tough Young Teachers (London, Victory Television).

Britzman, D. (2010) The Very Thought of Education: Psychoanalysis and the Impossible Professions (New York, SUNY Press).

Department of Education and Skills (Ireland) (2016a) School Self-Evaluation Guidelines 2016--2020: Post-Primary (Dublin, Stationary Office).

Department of Education and Skills (Ireland) (2016b) Looking At Our Schools (LAOS): A Quality Framework for Post-Primary Schools (Dublin, Stationery Office).

Fanon, F. (2001) The Wretched of the Earth. Translated from the French by C. Farrington (London, Penguin Classics).

Gadamer, H. (2004) Truth and Method. Translated from the German by J. Weinsheimer and D. G. Marshall (London and New York, Continuum International Publishing Group).

Goldstein, H. (1997) Methods in School Effectiveness Research. School Effectiveness and School Improvement. 8, pp. 369-395

Grek, S. and Lindgren, J. eds., (2014) Governing by Inspection (London, Routledge).

Harris, S. (2007) The Governance of Education: How Neo-Liberalism is Transforming Policy and Practice (London and New York, Continuum Books).

Hattie, J. (2008) Visible Learning: A Synthesis of Over 800 Meta-Analyses Relating to Achievement (London and New York, Routledge).

Hegel, G. W. F. (1998) The Phenomenology of Spirit. Translated from the German by A. V. Miller. (New Delhi, Motilal Banarsidass Publishers).

Heter, T. S. (2006) Authenticity and Others: Sartre's Ethics of Recognition, Sartre Studies International, 12.1, pp. 17-43.

Hislop, H. (2012) The Quality Assurance of Irish Schools and the Role of Evaluation: Current and Future Trends. Presented at The Professor Seamus O'Suilleabhain Memorial Lecture, Maynooth, 2 May 2012.

Honneth, A. (1996) The struggle for recognition: the moral grammar of social conflicts. Translated from the German by J. Anderson. Cambridge, MA: The MIT Press.

The Irish Times (2016) The Same-Sex Marriage Referendum. Available online at: http://www.irishtimes.com/news/politics/marriage-referendum [Accessed 06 November 2016].

Killen, R. (2006) Effective Teaching Strategies: Lessons from Research and Practice, (Melbourne, Cengage Learning). 
Kocsis, R. N. and Palermo, G. B. (eds) (2007) Contemporary Profiling: International Theory, Research, and Practice, (New Jersey, Humana Press Inc.).

Kocsis, R. N. and Palermo, G. B. (2015) Disentangling Criminal Profiling: Accuracy, Homology, and the Myth of Trait-Based Profiling. International Journal of Offender Therapy and Comparative Criminology. 59.1, pp. 313-332.

MacBeath, J. (1999) Schools Must Speak for Themselves: A Case for School Self-Evaluation (London and New York, Routledge).

McNamara, G. and O’Hara, J. (2008) Trusting Schools and Teachers: Developing Educational Professionalism through Self-Evaluation (New York, Peter Lang Publishers Inc.).

Richards, C. (2001) School Inspection in England: A Reappraisal, in: C. Winch and R. Smith (eds) Impact: No. 9 in a Series of Policy Discussions (London, Philosophy of Education Society of Great Britain).

Richards, C. (2015) More Outstanding Nonsense: A Critique of Ofsted Criteria, FORUM, 57.1, pp. 233-238.

Sartre, J. P. (1936) Transcendence of the Ego: An Existential Theory of Consciousness. Translated from the French by F. Williams and R. Kirkpatrick (New York, Hill and Wang).

Sartre, J.P. (1943) Being and Nothingness: An Essay on Phenomenological Ontology. Translated from the French by H. E. Barnes (London and New York, Routledge Classics).

Sartre, J. P. (1944) No Exit: A Play in One Act (New York, Vintage Books).

Sartre, J. P. (1946) Anti-Semite and Jew. Translated from the French by G. J. Becker (New York, Schoken Books).

Schratz, M. and Steiner-Loffler, U. (1998) Die lemende Schule, (Weinheim, Beltz Verlag).

Simmie, G. M. (2012) The Pied Piper of Neo-Liberalism Calls the Tune in the Republic of Ireland: An Analysis of Education Policy Text from 2000-2012, Journal for Critical Education Policy Studies, 10.2 , pp. 485-514.

Simons, M. (2015) Governing Education Without Reform: The Power of the Example, Discourses: Studies in the Cultural Politics of Education, 36.5, pp. 712-731.

Standish, P. (2014) Teachers Exposed: Education in Denial. Presented at the Boyd Bode Lecture. Available online

at: https://www.academia.edu/21604239/Teaching_Exposed_Education_in_Denial_The_Boyd_Bo de_Lecture_2014 [Accessed 06 November 2016].

Taylor, C. (1989) Sources of the Self: The Making of the Modern Identity (Cambridge, Cambridge University Press).

Taylor, C. (1991) The Ethics of Authenticity (Cambridge, MA, Harvard University Press).

Taylor, C. (1994) Multiculturalism: Examining the Politics of Recognition (Princeton, NJ, Princeton University Press). 